\title{
The Effects Of Oil Spills On Phytoplankton In An Arctic Lake And Ponds
}

\author{
MICHAEL C. MILLER, VERA ALEXANDER and \\ ROBERT J. BARSDATE
}

\begin{abstract}
The effect of oil spilled on Alaskan freshwater phytoplankton populations was studied in waters affected by natural oil seeps, by controlled crude oil spills in tundra thaw ponds and in a morainal lake, by subpond manipulations and bioassay experiments. The studies were carried out over a period of seven years. Regardless of dose the effects of oil were predictable in the small ponds. The zooplankton populations were virtually eliminated, and after an initial depression of primary productivity the photosynthetic rates returned to approximately prespill levels with a small increase in algal biomass. A markedly altered algal composition was an invariable effect of the response, with the elimination of a dominant flagellated form, Rhodomonas spp., in the case of the ponds. From the results of subpond manipulation experiments, evidence supports the hypothesis that elimination of grazers is the principal cause of altered species composition and increased biomass in these ponds. In our lake system there was a severe reduction in primary production during the season of the experimental spill. During the second year only the spring boom was supressed by the added oil. Bioassay experiments supported the hypothesis that in such lakes, direct inhibition of algal photosynthesis may be important, although zooplankton were greatly reduced.
\end{abstract}

RESUME. On a étudié les effets de fuites de pétrole sur les populations de phytoplancton d'eau douce en Alaska, celà dans les eaux polluées par des suintements naturels de pétrole, par des fuites artificielles dans des étangs dégelés de toundra et dans un lac glaciaire grâce à des manipulations au niveau des étangs et par des essais d'expériences biologiques.

Les études étaient réalizées sur une période de sept années. Sans considération de dosage, les effets du pétrole étaient prévisibles dans les petits étangs dégelés. Les populations de plancton étaient éliminées et après une diminution initiale de productivité primaire, le rendement de la photosynthèse remontait approximativement au niveau de ce qu'il était avant la pollution, avec une petit accroissement du biotope. La composition clairement altérée de la population était invariablement l'image résultante, avec la disparition d'une forme typique de ces étangs (Rhodomonas minuta). Les résultats acquis, suite aux expériences de manipulation au niveau des étangs, demontraient avec évidence, l'hypothèse que la disparition des espèces rasantes est la principale cause de la composition altérée des espèces et de l'accroissement du biotope dans ces étangs.

En système lacustre, il y avait une réduction sévère dans la productivité primaire au cours de la saison des fuites expérimentales. Pendant la seconde année seul l'épanouissement printanier sous la glace disparaissait par l'addition de pétrole. Les essais d'expérience biologique confirmaient l'hypothèse que dans de tels lacs, la disparition directe des algues de photosynthèse pouvait être importante.

Traduit par Alain Vendigies, Aquitaine Co. of Canada Ltd.

\section{INTRODUCTION}

In this paper we will discuss and synthesize results from three distinct approaches to the problem of crude oil effects on arctic freshwater 
phytoplankton populations. Our first observations involved a continuous natural oil seep at Cape Simpson $\left(71^{\circ} \mathrm{N}\right.$ lat.) and this work has been described in detail in Barsdate, et al. (1973). Following this, two experimental thaw pond spills were carried out in the Pt. Barrow, Alaska area $\left(71^{\circ} \mathrm{N}\right.$ lat.). The first of these was done during the International Biological Program Tundra Biome study period, with results included in several publications and reports (Alexander, et al., 1972; Alexander and Coulon, 1973; Barsdate and Prentki, 1973; Stanley, 1973). The second more recent spill has been discussed in Miller et al. (1977), Miller, et al. (1978). The third approach used a contained spill in a morainic lake in the foothills north of the Brooks Range on the Trans-Alaska Pipeline road $\left(68^{\circ} \mathrm{N}\right.$ lat.) (Barsdate and Alexander, pers. comm.).

Preliminary observations at the natural oil seep (to be discussed further below) showed inhibition or enhancement or algal primary production, changes in phytoplankton population composition and reduction of zooplankton populations above or below some critical oil dose. Several mechanisms for action of oil on phytoplankton could be evoked and partially evaluated as a result of the work. These include immediate toxicity by the soluble aromatic fraction, prolonged toxicity by persistent products, and altered physical-chemical conditions below the floating oil (temperature changes, for example). At non-toxic levels of oil, responses could include enhancement of metabolism due to increased nutrient availability from oil degradation, stimulation of nitrogen-fixing algae and bacteria or increased leaching of nutrients from vascular macrophyte stands. Two additional factors to be considered are the effects on phytoplankton of removal of grazing pressure (through toxicity to zooplankton) and possible competitive monopolization of nutrients by oil degrading heterotrophs. Data from our work will be considered with reference to these possibilities.

Our primary approach was to treat whole or parts of natural water bodies with oil, with the aim of comparing phytoplankton response to crude oil over a range of dosages, to determine the mechanisms involved in the response, to follow the recovery of the phytoplankton and to assess the effects of the treatment on ecosystem structure and function. Either adjacent similar ponds or portions of the lake not exposed to oil were used as controls. All the spills were done in different years.

\section{Oil Spill Application}

METHODS

For the experimental pond spills typical tundra thaw ponds were selected in the.U.S. Tundra Biome Aquatic site near the Arctic Ocean at Barrow, Alaska. The pond used in 1970 was designated ' $E$ ' and the pond used in 1975 was designated 'Omega'. These water bodies were separated enough that at no time was there contact between these ponds and the pond used as the major control, Pond ' $\mathrm{C}$ ', on which much background information was available (Hobbie, in prep., Fig. 1). A fourth pond, Pond 'B', was also used as a control during the former pond oil spill. The experimental lake (Oil Lake) spill was 


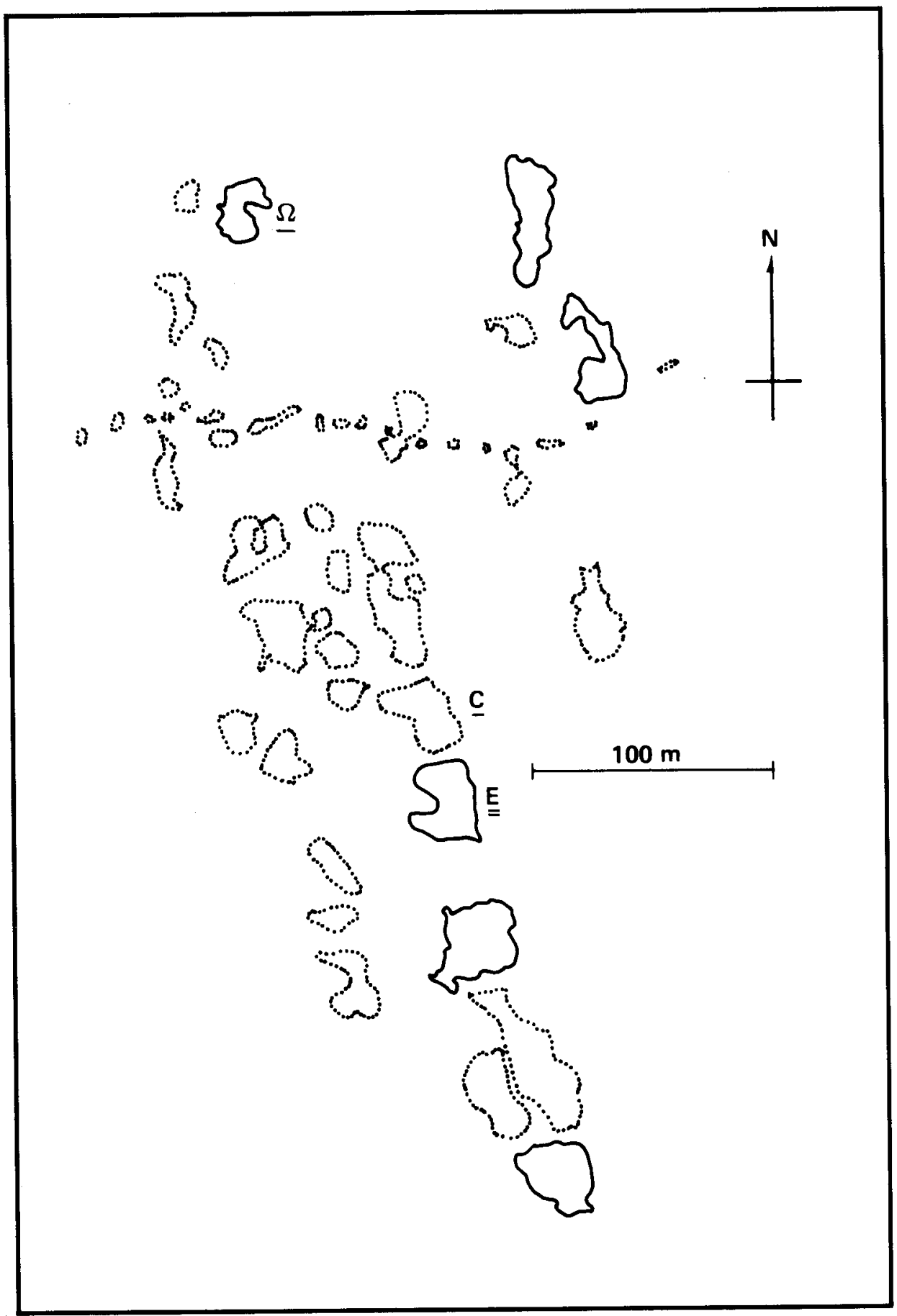

FIG. 1. The experimental pond site at Pt. Barrow, Alaska showing control Pond $\mathrm{C}$ and the two oil spill ponds, Pond E and Pond Omega. 
contained by a sea curtain which confined an area of $816 \mathrm{~m}^{2} 1.4 \mathrm{~m}$ average depth. The curtain, procured from Kempner Plastics of Torrence, California was $91 \mathrm{~m}$ long and consisted of an $0.2 \mathrm{~m}$ diameter float supporting a freehanging vertical skirt with a depth of 3.7 to $4.9 \mathrm{~m}$ (Fig. 2). The ends were anchored to shore above the highest water level and the floating collar was anchored at many points by lines to weights on bottom to prevent its being moved by winds and waves. In contrast to the ponds, the Oil Lake was 198 $\mathrm{km}$ south of Prudhoe Bay located in the foothills of the Brooks Range (Phillip Smith Mountains) where the thaw was almost a month earlier than for similar lakes near Barrow and the average summer temperatures about $5{ }^{\circ} \mathrm{C}$ warmer. The oil dose rates varied over a 100 -fold range (Table 1).

\section{Biological and Chemical Methods}

Since several independent investigators were involved in the work discussed, similar but not identical techniques were used. We will not go into detail on these, since they have been described in the publications referenced above. Algal primary productivity was measured by the ${ }^{14} \mathrm{C}$ method described by Vollenweider (1969), with liquid scintillation counting used for all but the Pond E work when a Geiger Müller planchet counter was used. All incubations were done in situ with $125 \mathrm{ml}$ glass-stoppered bottles suspended at 1 or 2 depths in the ponds and at $0.5,1,2,4$, and $8 \mathrm{~m}$ in Oil Lake (Fig. 2). Physical and chemical parameters were measured using standard techniques (Strickland and Parsons, 1968; Standard Methods, 1975). Nitrogen fixation was measured by acetylene reduction (Alexander and Schell, 1973). Phytoplankton were settled and enumerated by inverted microscopic measurement (Utermohl, 1958). Zooplankton were collected in dip buckets from around each pond (Stross, 1974) and by Schindler trap (1969) from Oil Lake. In addition to in situ effects, phytoplankton response to various oil concentrations was studied in bioassay experiments in Oil Lake. For this work, oil was added to lake water in duplicate Pyrex ${ }^{R}$ bottles to achieve a graded series of concentrations using 6, 12, and 24 hour incubations with ${ }^{14} \mathrm{C}$-labelled bicarbonate to determine short-term effects on phytoplankton photosynthesis under constant light (fluorescent light bank) at $10^{\circ} \mathrm{C} \pm 2{ }^{\circ} \mathrm{C}$ or under in situ conditions. In the first part of 1976, the oil and lake water was equilibrated using a wrist action shaker. Subsequently, oil and water was first blended in a Waring blender at high speed, and aliquots added to the lake water samples, with hand shaking to mix.

Since zooplankton grazing was possibly a major factor in phytoplankton population control (both in terms of biomass and species composition), the effects of oil alone and of zooplankton were studied using a series of duplicate subponds. These consisted of plastic garbage pails each containing 181 of Pond C (control) water. Treatments were set up in duplicate on 25 June 1976 as follows: 1) zooplankton without oil, 2) no zooplankton or oil, 3) oil without zooplankton, and 4) oil and zooplankton both present. Oil was added to produce a concentration of $1.2 \mathrm{ml} \mathrm{liter}^{-1}$, as in Pond Omega initially. 


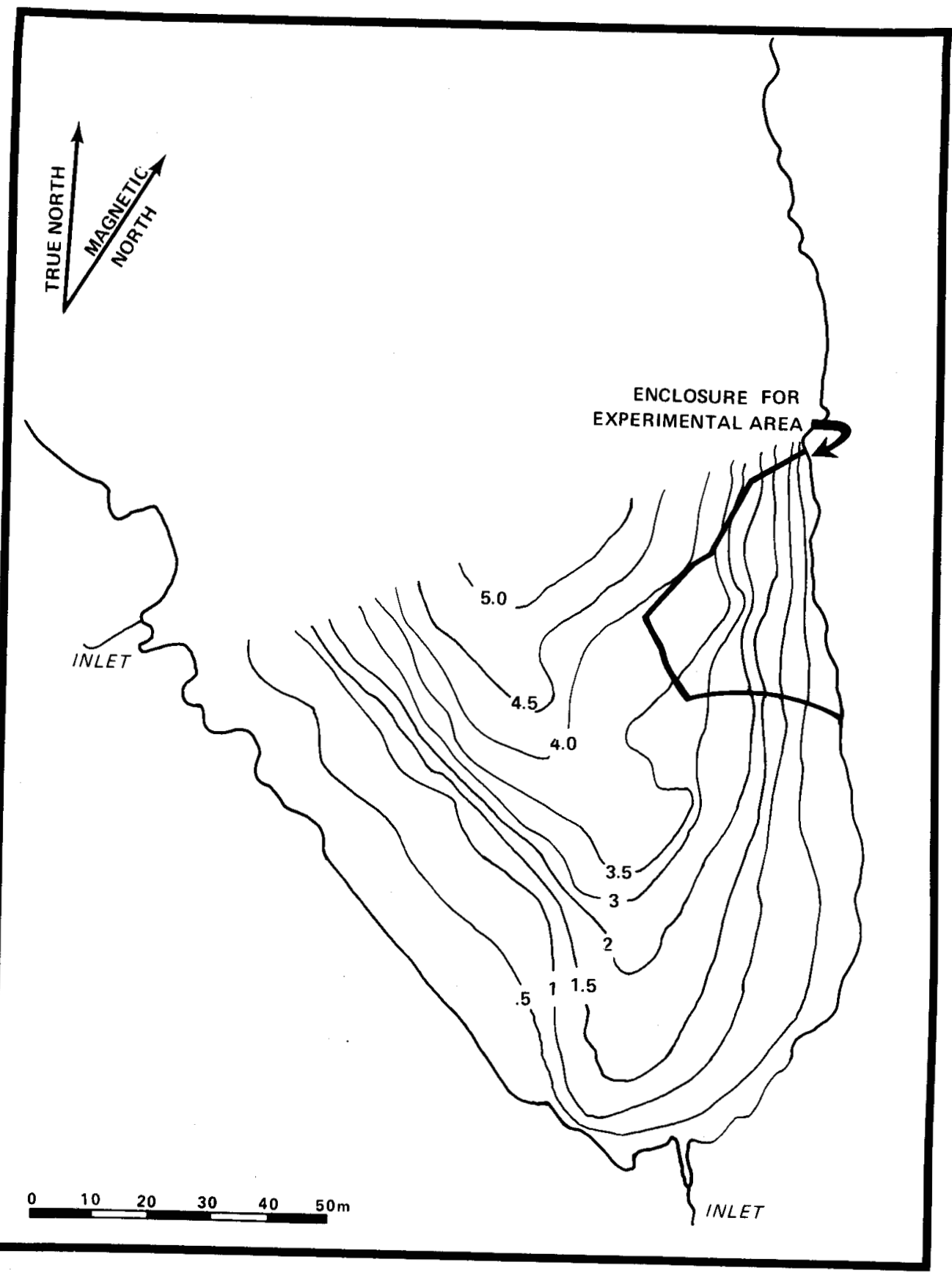

FIG. 2. Oil Lake ( $200 \mathrm{~km}$ south of Prudhoe Bay on the Pipeline Haul Road) showing the site of
the sea curtain. 
TABLE 1. Pond morphometry, experimental oil dose, and approximate $\mathrm{N}$ and $\mathrm{S}$ added in the Prudhoe crude oil

\begin{tabular}{|c|c|c|c|c|c|c|c|c|}
\hline \multirow[b]{2}{*}{ POND } & \multirow[b]{2}{*}{$\begin{array}{c}\text { Area } \\
\mathrm{m}^{2}\end{array}$} & \multirow[b]{2}{*}{$\underset{\mathrm{m}}{\text { Mean Depth }}$} & \multirow[b]{2}{*}{$\begin{array}{l}\text { Date of } \\
\text { Spill }\end{array}$} & \multirow[b]{2}{*}{$\begin{array}{l}\text { Amount of } \\
\text { Oil Spilled }\end{array}$} & \multirow[b]{2}{*}{$\begin{array}{l}\text { Dose of oil } \\
\text { liters } / \mathrm{m}^{2}\end{array}$} & \multirow[b]{2}{*}{$\mathrm{ml} /$ liter } & \multicolumn{2}{|c|}{$*$} \\
\hline & & & & & & & $\underset{\mathrm{mg} / \mathrm{l}}{\mathrm{N} \text { in oil }}$ & $\begin{array}{c}\mathrm{S} \text { in oil } \\
\mathrm{mg} / \mathrm{l} \text { in pond }\end{array}$ \\
\hline $\mathbf{E}$ & 300 & 0.26 & 16 July, 1970 & $\begin{array}{c}760 \text { liters } \\
\text { (200 (gal.) }\end{array}$ & 2.5 & 13 & 19.5 & 69 \\
\hline Omega & 280 & 0.20 & 10 July, 1975 & $\begin{array}{l}64 \text { liters } \\
\text { (18 gal.) }\end{array}$ & 0.24 & 1.4 & 2.4 & 8.4 \\
\hline Oil Lake curtain & 816 & 1.4 & 28 July, 1976 & $\begin{array}{l}208 \text { liters } \\
\text { (55 gal.) }\end{array}$ & 0.25 & 0.18 & 0.3 & 1.2 \\
\hline Subponds, Pond C & 0.056 & 0.31 & 25 June, 1976 & 0.018 liters & 0.31 & 1.0 & 2.0 & 7.3 \\
\hline
\end{tabular}

*Sulfur is $0.82 \%$ by weight and Nitrogen is $0.23 \%$ by weight in Prudhoe Bay crude oil (Thompson et al., 1971). 
Zooplankton additions consisted of one fairy shrimp (Branchinecta paludosa O. F. Müller) and two Daphnia middendorfiana Fischer per liter. This zooplankton abundance lies within the range of average densities reported by Stross (1974). The subponds were sampled at $0,5,15$, and 41 days after treatment for productivity algal biomass and species composition.

The control site for Oil Lake was selected in an area removed from the boom. Here, water depth was approximately $10 \mathrm{~m}$. Although less comparable to the depth inside the boom, this area was considered more representative for obtaining general limnological information for Oil Lake than a shallower nearshore station. Sampling was done inside and outside the boom using separate equipment and boats to avoid cross contamination.

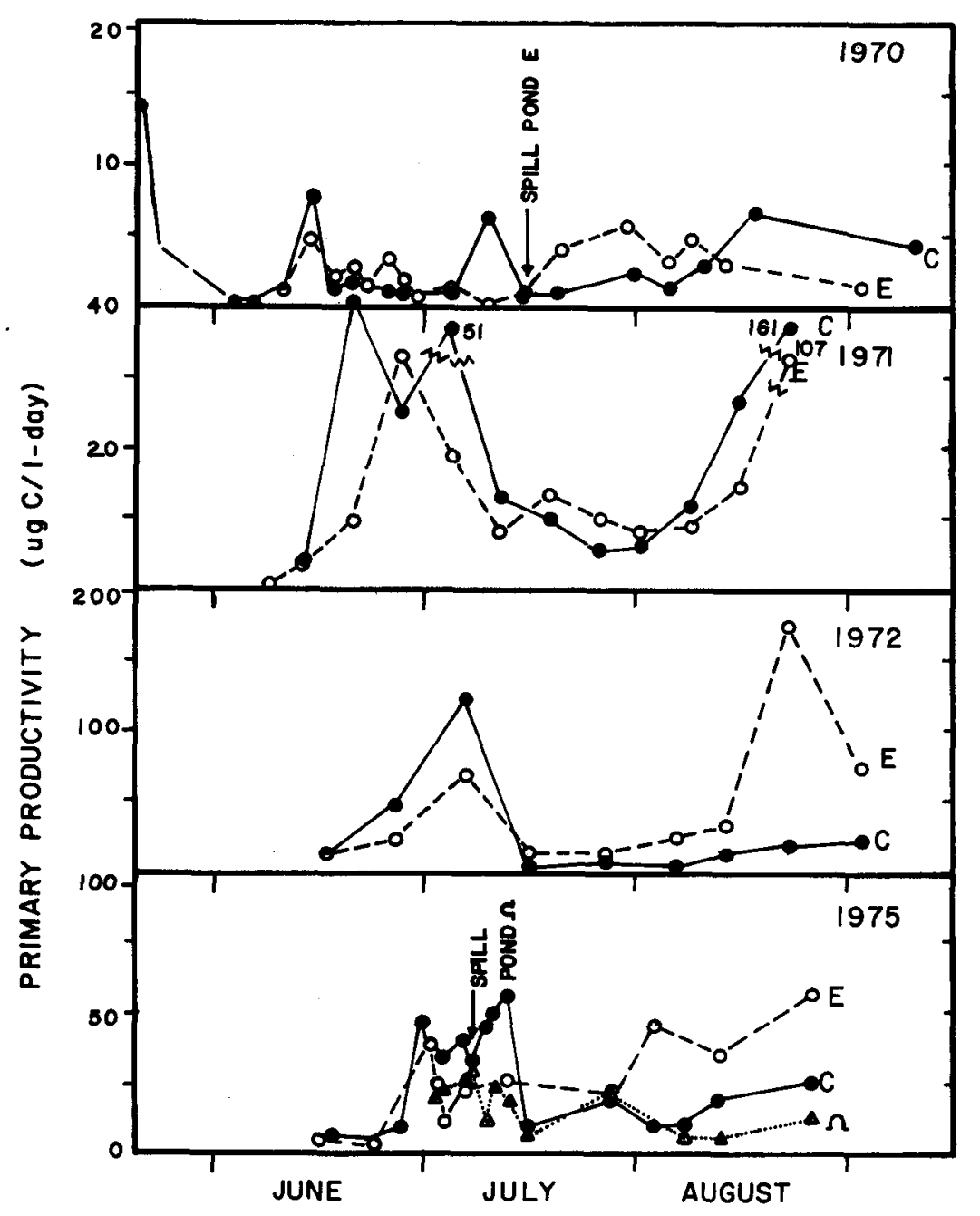

FIG. 3. Primary productivity ( $\mu$ g C 1-1 day $\left.{ }^{1}\right)$ in Pond E, Omega and C 1970-75. 
Fate of Oil

\section{RESULTS}

The four barrels of crude oil (760 l) covered all of Pond E $\left(300 \mathrm{~m}^{2}\right)$, but after 24 hours the wind had moved the oil to the west side where it accumulated in a band 3 to $5 \mathrm{~m}$ wide. During August, the oil moved back and forth with the wind, with about one half remaining in the emergent vegetation zone. In July, a year later, some floating oil was still visible and the odor of oil was evident. Thick accumulations which had sunk as the water level fell the year before remained attached to the plant litter in the Carex aquatilis Wahl. bed. We estimated that at least one half the oil was still present after one year. By 1975 occasional oil slicks and small patches of floating oil were seen only in the Carex beds on the west side, where the surface of the tar had become brown with a covering of organic detritus.

Although the spill on Pond Omega involved a lower oil concentration (0.25 $1 \mathrm{~m}^{2}$ or $1.4 \mathrm{ml}^{1}$ ), the oil weathered in much the same manner. The buildup of tar appeared less significant and the floating oil scum absorbed particulate material as it weathered until it became brittle. Oil loss rate on the surface of open cores was about 3\% per day after a week (Miller et al. 1978). By June of $197658 \%$ by weight of the initial crude oil could be recoyered pentane extraction from the open cores (Federle et al. 1978). Although weathering and degradation on open core tubes may not have been exactly analogous to weathering on the pond it does indicate that, unlike sub-arctic spills (Snow and Rosenberg, 1975), the degradation of crude oil in the arctic is slow (Federle et al., 1978).

\section{Effects of Oil on Primary Productivity}

Primary productivity was first measured four days after the spill on Pond E on 16 July 1970 and was higher than in the control ponds for the next 20 days (Fig. 3). The annual primary productivity was, however, not different from that in Pond $C$ due to an August bloom in the latter (Table 2). In 1971 the Pond E productivity was 30\% lower than in the control pond and in 1972 exceeded the control by $115 \%$. The average measured productivity of Pond $E$ was not within pond-pond variation in 1975 and 1976.

The immediate response following the Pond Omega spill on $10 \mathrm{July,} 1975$ was inhibition which persisted for 6 days (Miller et al., 1978). By day 18, however, the production was higher proportionately than in the control pond C. Overall carbon input for the $\mathbf{4 5}$ days following the oil spill was $28 \%$ less than in the control pond, and in the following year the production was $35 \%$ less than the control pond on the dates tested (Table 1, Miller et al., 1978). Thus, stimulation and inhibition in the summer of the spill and inhibition in the subsequent year occurred in both pond spills.

In the case of the spill in Oil Lake, almost immediately after oil addition (within the area enclosed by the boom), primary production ( $0-3 \mathrm{~m}$ integrated) decreased significantly compared with the control station outside (Fig. 2). This effect continued throughout the remainder of the season (Figs. 4-6). 
Chlorophyll and Primary Productivity $0.5 \mathrm{~m}$ depth.

Oil Lake 1976 (in situ incubation, July - September)

$19760.5 m$

Oil Lake
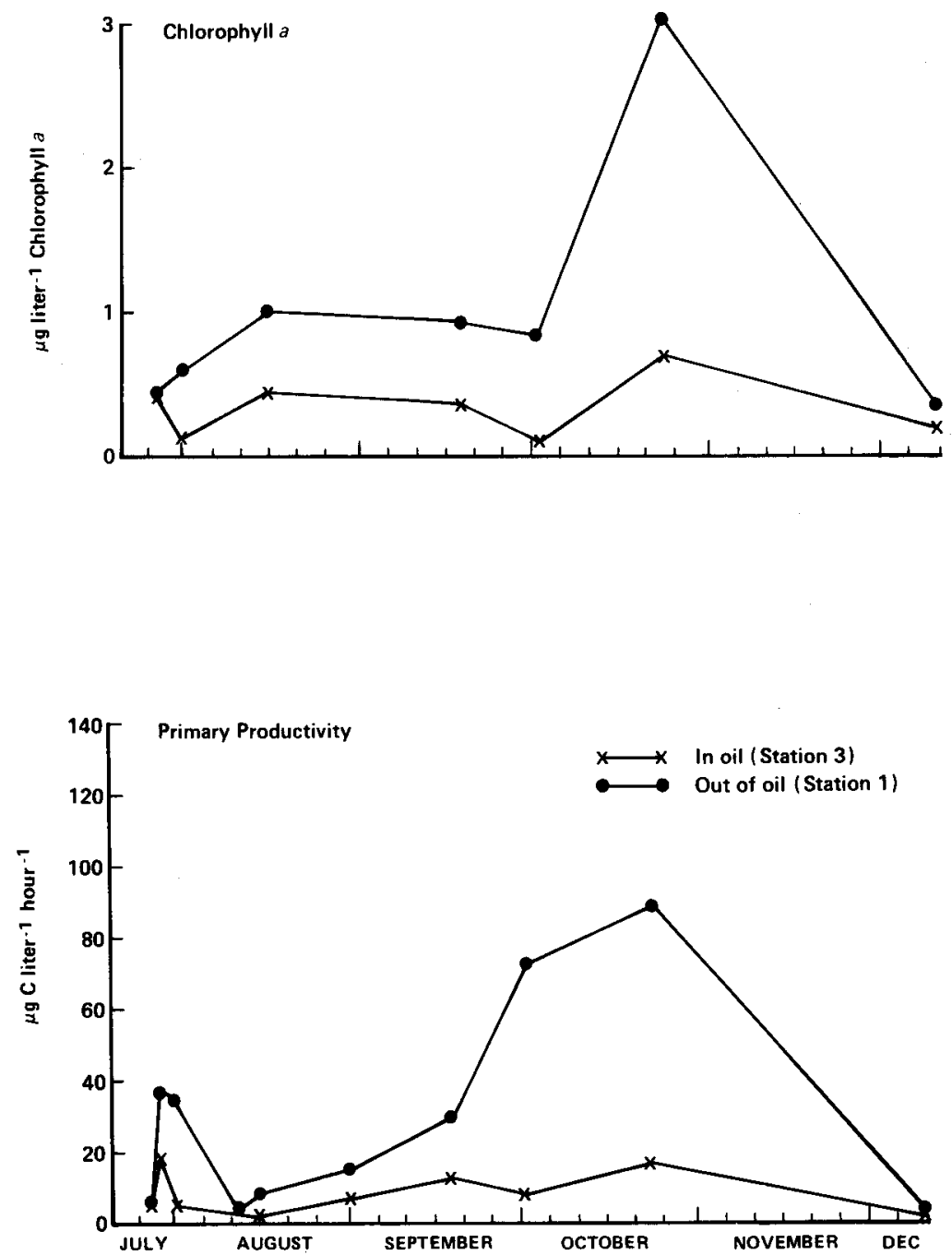

FIG. 4. Primary productivity $\left(\mu \mathrm{g} \mathrm{C}^{-1} \mathrm{hr}^{-1}\right)$ and chlorphyll $a\left(\mathrm{~g} \mathrm{t}^{-1}\right)$ concentrations in Oil Lake $(0.5 \mathrm{~m})$ and behind the sea curtain in 1976. 
Primary Productivity in upper 3 meters, Oil Lake, 1976.

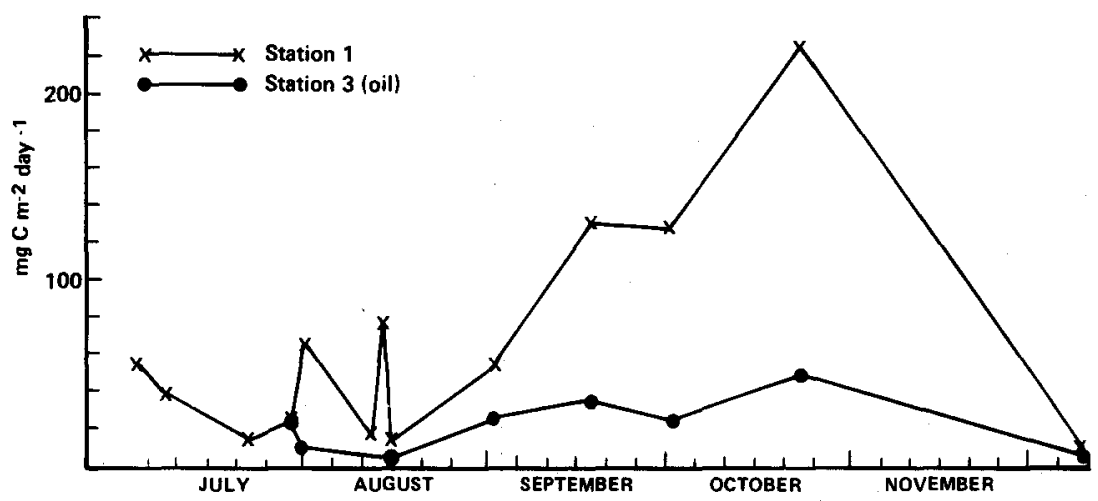

FIG. 5. Primary productivity integrated for the top three metres $\left(\mathrm{mg} \mathrm{C} \mathrm{m}^{2}\right.$ day-1) in Oil Lake and behind the sea curtain in 1976.

During the following year (1977) the inhibition was somewhat attenuated or absent, and was severe only during the spring productivity peak under the ice (Fig. 7). Results from short-term bioassay experiments on Oil Lake control water show that inhibition of photosynthesis is severe at $5 \mathrm{ppm}$ crude oil within 24 hours and further resolution at lower hydrocarbon doses shows that amounts as low as $2 \mathrm{ppm}$ caused a severe (50\%) reduction in photosynthesis (Figs. 8-9). Further prolonged exposure to oil within the boom did not result in adaptation and a lowered sensitivity in the bioassay experiments. Parallel experiments inside and outside the oiled area using fresh oil show no apparent differences in response (Fig. 10a, b).

\section{Effects of Oil on Algal Biomass}

Algal biomass (total cell volume and chlorophyll $a$ ) was $140 \%$ of the control following the 1970 Pond $\mathrm{E}$ spill. It was higher before the spill and remained so during the remainder of 1970 and through the 1971, 1972 and 1975 summer seasons. In 1976 the sixth year after the spill algal cell biomass in the two ponds was essentially identical (Table 2). In Pond Omega the algal biomass was similarly greater than in Pond $\mathrm{C}$ six days after the spill and remained higher on six of seven dates during the next forty-five days (Miller $e t$ al., 1978, Fig. 3). In the second year, however, the algal biomass in Pond Omega was only $50 \%$ that of the control pond C (Table 1). Both whole pond 
Selected depth plots of Primary Productivity - 1976
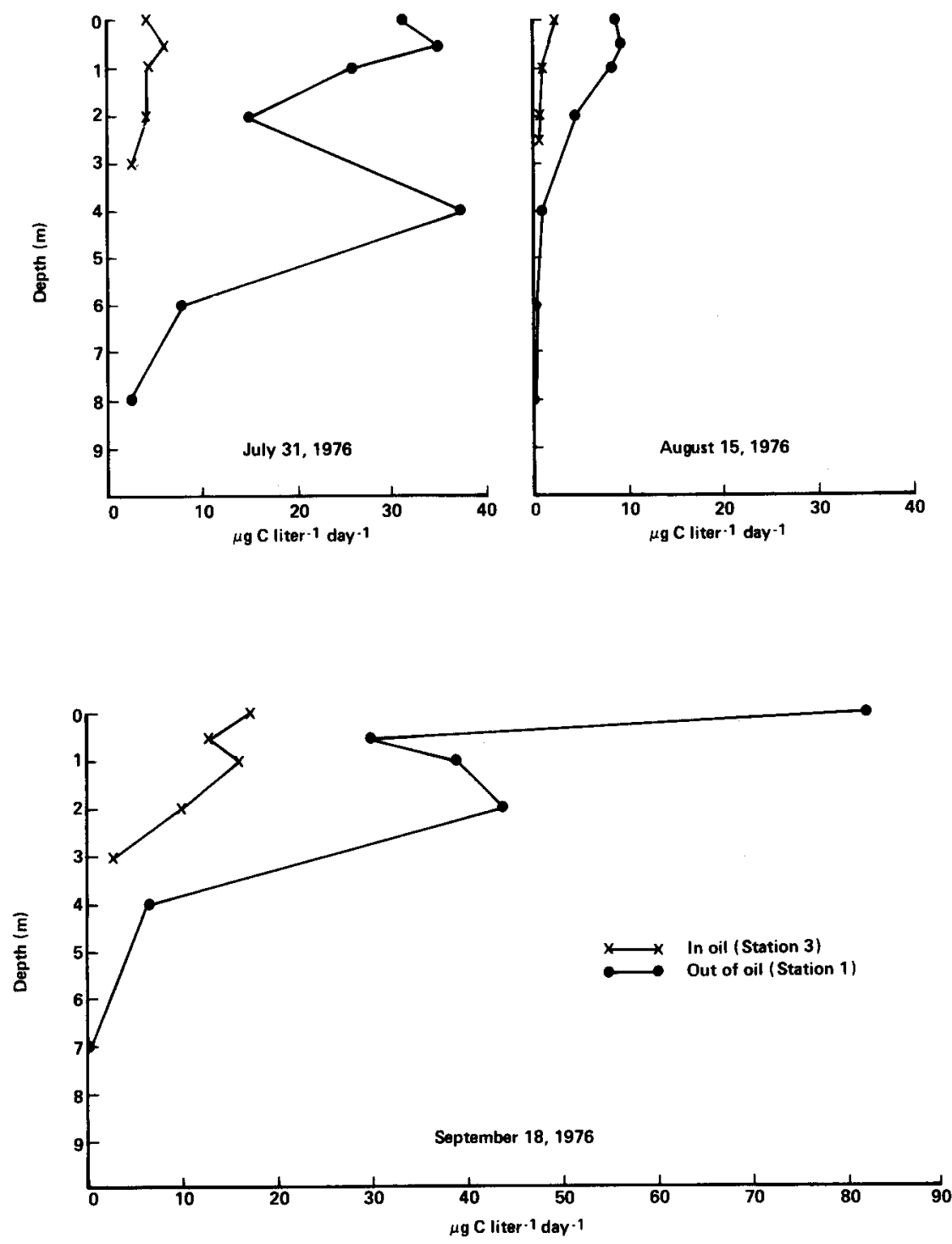

FIG. 6. Selected depth profiles of primary productivity inside and outside of the sea curtain in Oil Lake in 1976. 
spills showed increased biomass following the spill. However, during the second year, algal biomass was lower in Pond Omega on most occasions until August than in Pond C (Table 2).

Phytoplankton biomass, as expressed by chlorophyll $a$, showed a significant decrease following the oil introduction in Oil Lake (1976) and remained depressed throughout the remainder of the season (Figs. 4 and 11). The carbon fixed: chlorophyll ratio did not differ significantly between the oil impacted and control stations.

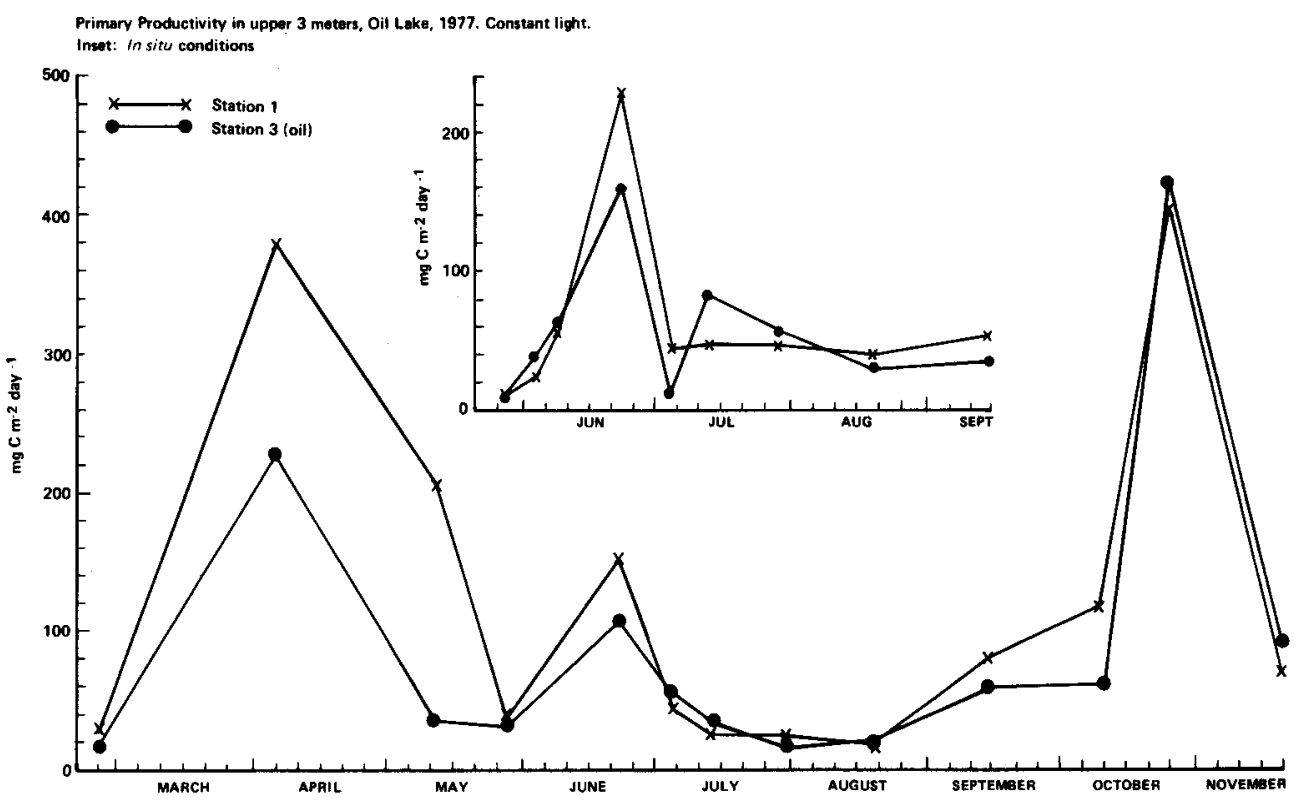

FIG. 7. Primary productivity integrated for the top three metres $\left(\mathrm{mg} \mathrm{C} \mathrm{m}^{-2}\right.$ day-1) incubate in situ and under constant light inside and outside the sea curtain in Oil Lake, 1977.

\section{Effects of Oil on Species Composition}

The normal seasonal cycle in Pond C (control) begins with Chrysophyta (primarily Chromulina with Pseudokephyrion and Mallomonas) dominant in the early part of the season. The Cryptophyte Rhodomonas minuta is the dominant during July and August (Alexander et al., 1972; Miller et al., 1978). Both Pond $\mathrm{E}$ and Pond Omega began the season of planned spill showing the same dominant as Pond C. Species variation between ponds was greatest during melt and/or late August. The response of the plankton species was the same in both spills. Within ten days following the spills in Pond E and Pond Omega, Rhodomonas had been eliminated (Fig. 12a, b). Chrysophyta Uroglena, Chlorophyta Chlamydomonas and Pyrrophyta (dinoflagellates) became common 
(Miller et al., 1978; Alexander et al., 1972). Uroglenopsis americana, a flagellated Chrysophyte species changed from a free-swimming to a large colonial form in the oil ponds, forming large round balls of cells on the bottom and attached to vegetation. This species seemed common after oil spills. In 1970 it dominated the biomass 20 days after the spill on Pond E (Fig. 12). Rhodomonas was found in neither pond in the year following the spill and although it was found on one date in 1972, it remained of minimal importance in 1976 (Federle et al., 1978). Rhodomonas had been absent in the moderately to severely oil affected ponds at the Cape Simpson seeps (Barsdate et al., 1973). Changes in species composition induced by crude oil exposure were the most predictable features of the natural and experimental spills over a very wide range in dose.

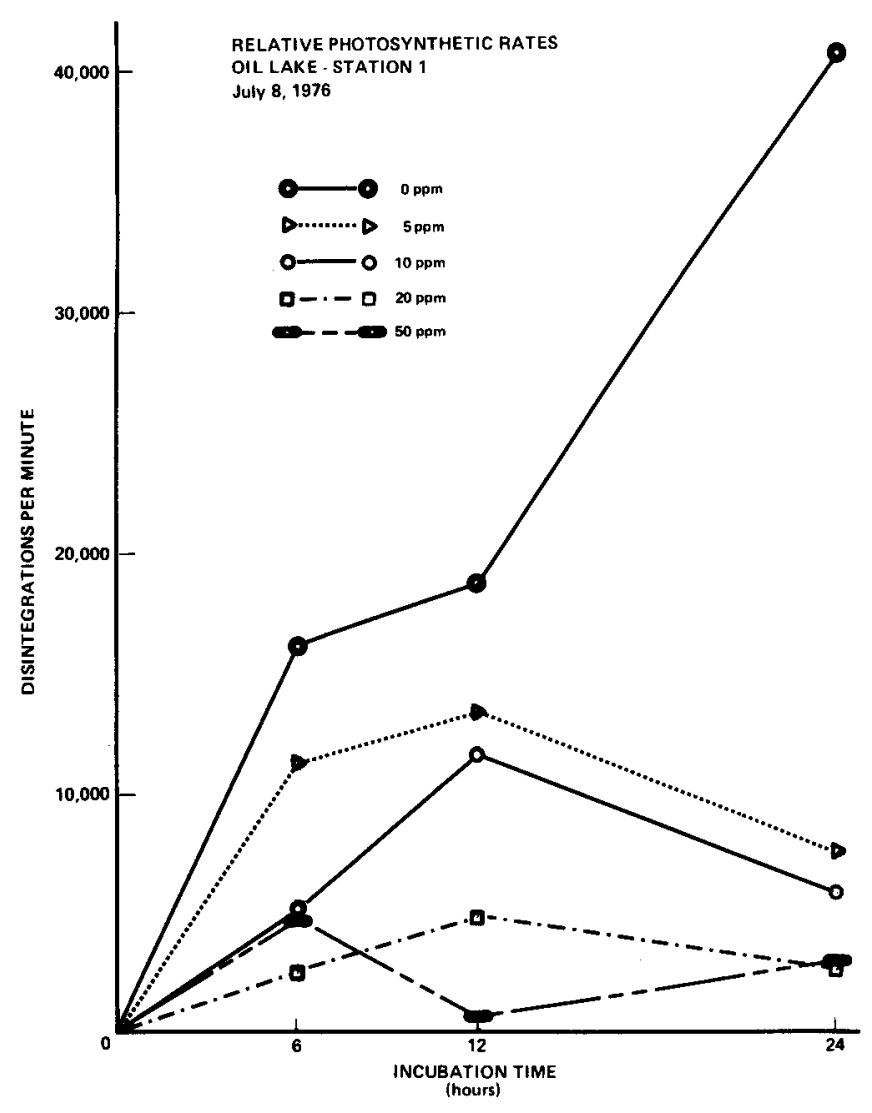

FIG. 8. Bioassay for the toxicity of crude oil to the phytoplankton in Oil Lake, July 8, 1976. 
TABLE 2. Average primary productivity, chlorophyll concentration and algal density (biomass) in control and experimental oil spill ponds - Pond E (1970) and Pond Omega (1975) (Parenthetical values in the table are standard

\begin{tabular}{|c|c|c|c|c|c|c|c|c|c|}
\hline Year/Pond & \multicolumn{3}{|c|}{ POND C (CONTROL) } & \multicolumn{3}{|c|}{ POND E (1970) } & \multicolumn{3}{|c|}{ POND OMEGA (1975) } \\
\hline 1970 Prespill $^{1}$ & $\begin{array}{l}0.285 \\
(0.435)\end{array}$ & $\begin{array}{l}0.722 \\
(0.482)\end{array}$ & $\begin{array}{l}1.44 \\
(0.68)\end{array}$ & $\begin{array}{l}0.222 \\
(0.125)\end{array}$ & $\begin{array}{l}1.82 \\
(3.19)\end{array}$ & $\begin{array}{l}1.93 \\
(0.63)\end{array}$ & & & \\
\hline 1971 & $\begin{array}{l}1.27^{6} \\
(1.02)\end{array}$ & $\begin{array}{l}0.792^{3} \\
(0.232)\end{array}$ & & $\begin{array}{l}0.92 \\
(0.81)\end{array}$ & $\begin{array}{l}0.908 \\
(0.558)\end{array}$ & & & & \\
\hline 1972 & $\begin{array}{l}2.8^{4} \\
(2.4)\end{array}$ & $\begin{array}{l}0.816^{3} \\
(\mathrm{n}=3) \\
\left(\mathrm{um}^{3} / 1\right)^{8}\end{array}$ & & $\begin{array}{l}3.22 \\
(2.97)\end{array}$ & $\begin{array}{l}1.04 \\
(0.82) \\
\left(\mathrm{um}^{3} /\right)^{8}\end{array}$ & & & $\left(\mathrm{um}^{3} /\right)^{8}$ & \\
\hline $1976^{7}(n=2)$ & 2.82 & 135.6 & 1.92 & 1.84 & 130.7 & 1.40 & 0.54 & 76.6 & 1.38 \\
\hline
\end{tabular}
1) Alexander, Clasby, Coulon 1971
4) Stanley 1973
7) Federle et al. 1978

2) Alexander-
5) Miller et al. 1978
8) cell volume $\mathrm{um}^{3} \times 10^{6} /$ liter

3) Alexander and Coulon 1973

6) Miller and Reed 1973 


\section{Subpond Experiments}

One feature of all the oil-exposed ponds, regardless of dose rates, was the elimination of the dominant zooplankton Daphnia middendorfiana (Fischer) and the fairy shrimps Brachinecta paludosa (O. F. Müller) and Polyartemiella hazeni (Murdoch). The zooplankton were killed within six days of the spill (O'Brien, this volume). In 1976, four sets of duplicate subponds (18 1 polyethylene garbage cans with bottoms) were filled with Pond C (65 $\mu \mathrm{m}$ mesh) water and phytoplankton. Zooplankton were added or removed from four and oil added to a pair of each. To those receiving zooplankton, 36 Daphnia and 18 fairy shrimp were added before they reproduced ( 25 June). Fresh crude oil was added directly to the surface (unstirred) to one set containing zooplankton and one set without. The oil eliminated all zooplankton within three days. In the zooplankton controls without oil, the Daphnia reproduction so that 60 and 68 young with 23 and 10 adults, respectively, were found remaining on 6 August. Most of the fairy shrimp had died by the end of the experiment (three and one/subpond, respectively), presumably because they require algae from the epibenthos not present in the subponds.

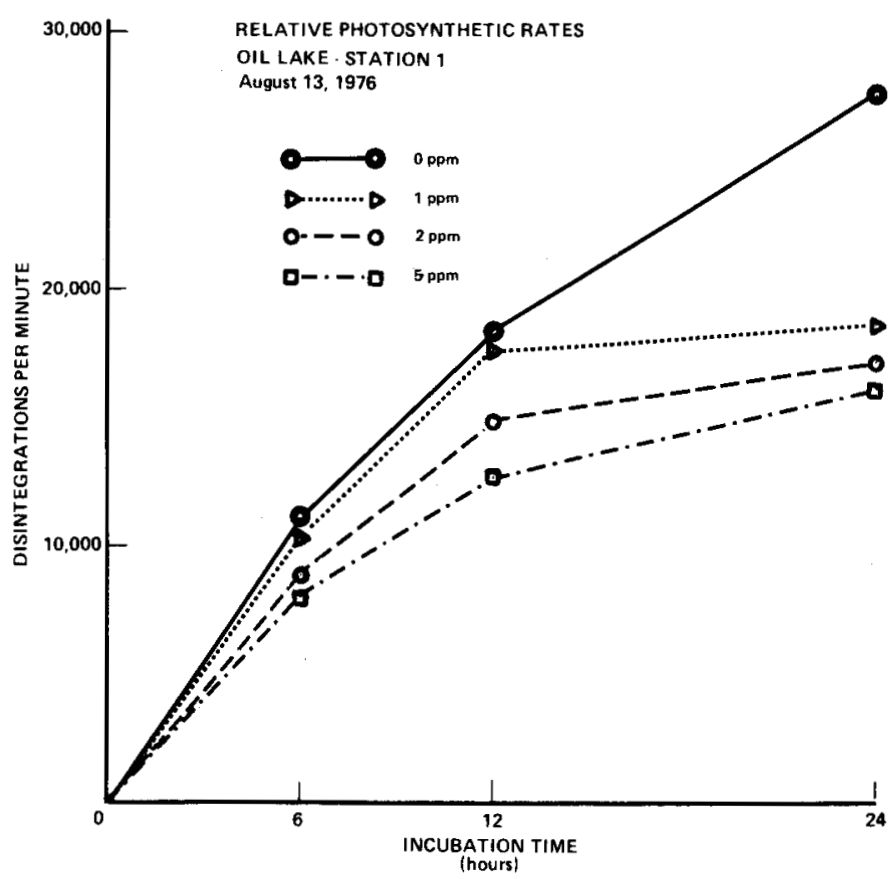

FIG. 9. Bioassay for the toxicity of crude oil in the $1-5 \mathrm{ppm}$ range to the phytoplankton in Oil Lake, August 13, 1976. 

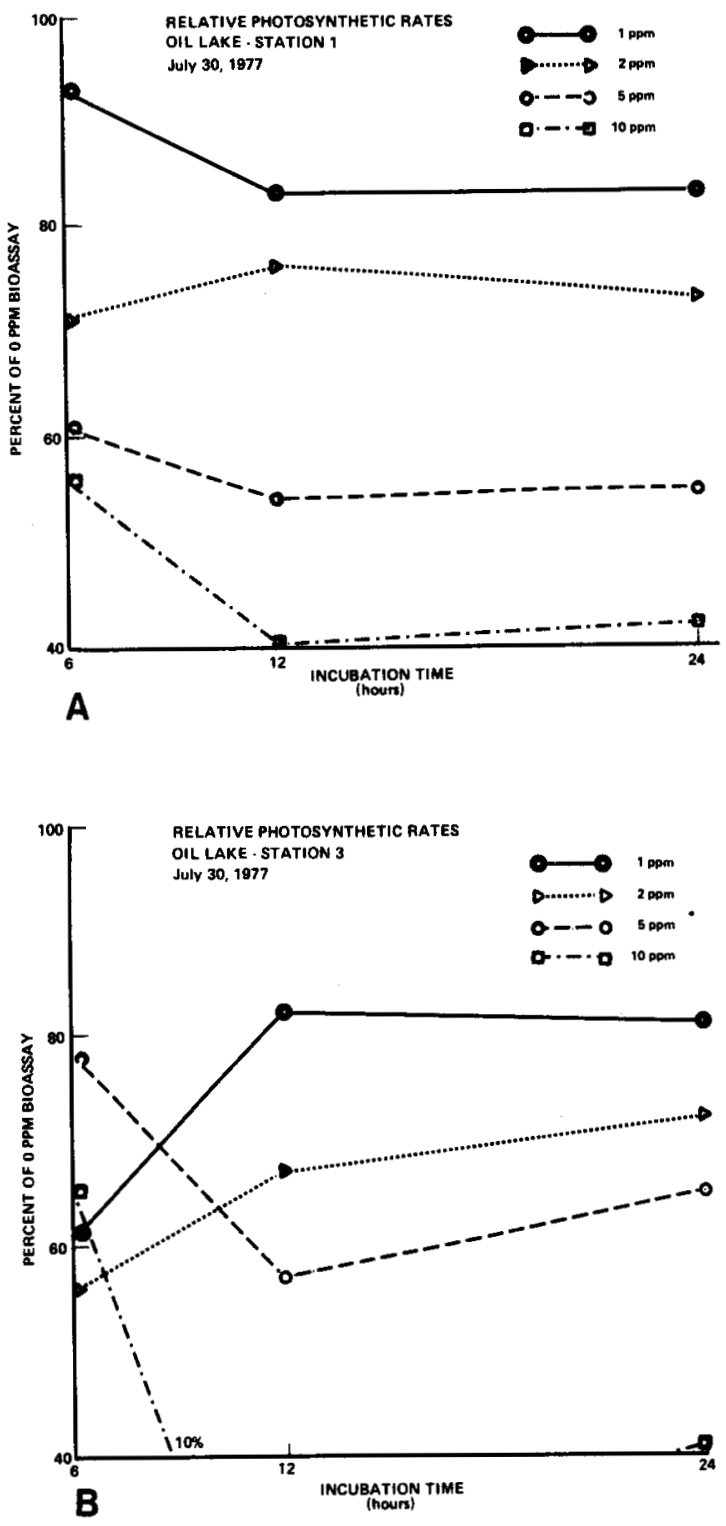

FIG. 10. $a$ and $b$. Bioassay for the toxicity of crude oil inside and outside the sea curtain in Oil Lake on July $30,1977$. 
Primary production increased dramatically (five-fold) in 15 days in the oil-free, zooplankton-free subponds (treatment 2) compared to oil-free control subponds with zooplankton (treatment 1) Federle et al., 1978). In those receiving oil (treatments 3 and 4) primary production decreased to near zero after five days and then recovered slightly to $70 \%$ of that in treatment 1 (zooplankton but no oil). The algal biomass showed the same pattern of spectacular growth after 15 days in the subpond lacking zooplankton. Compared to zooplankton control, algal biomass increased continuously from its minimum five days after receiving oil in the treatments receiving oil. The final chlorophyll concentration after 41 days in all treatments without zooplankton (treatments 2, 3 and 4) were minimally 10x that in treatment 1 containing zooplankton.

The most dramatic change by treatment occurred in species composition. Initially the ponds were dominated by Cryptophyta (Rhodomonas sp.) and Chrysophyta. After 15 days, Rhodomonas sp. had become undetectable in the oil treated subponds, treatments 3 and 4 , whereas the Chrysophytes (Chrysococcus, Chromulina and Ochromonas, had become almost completely

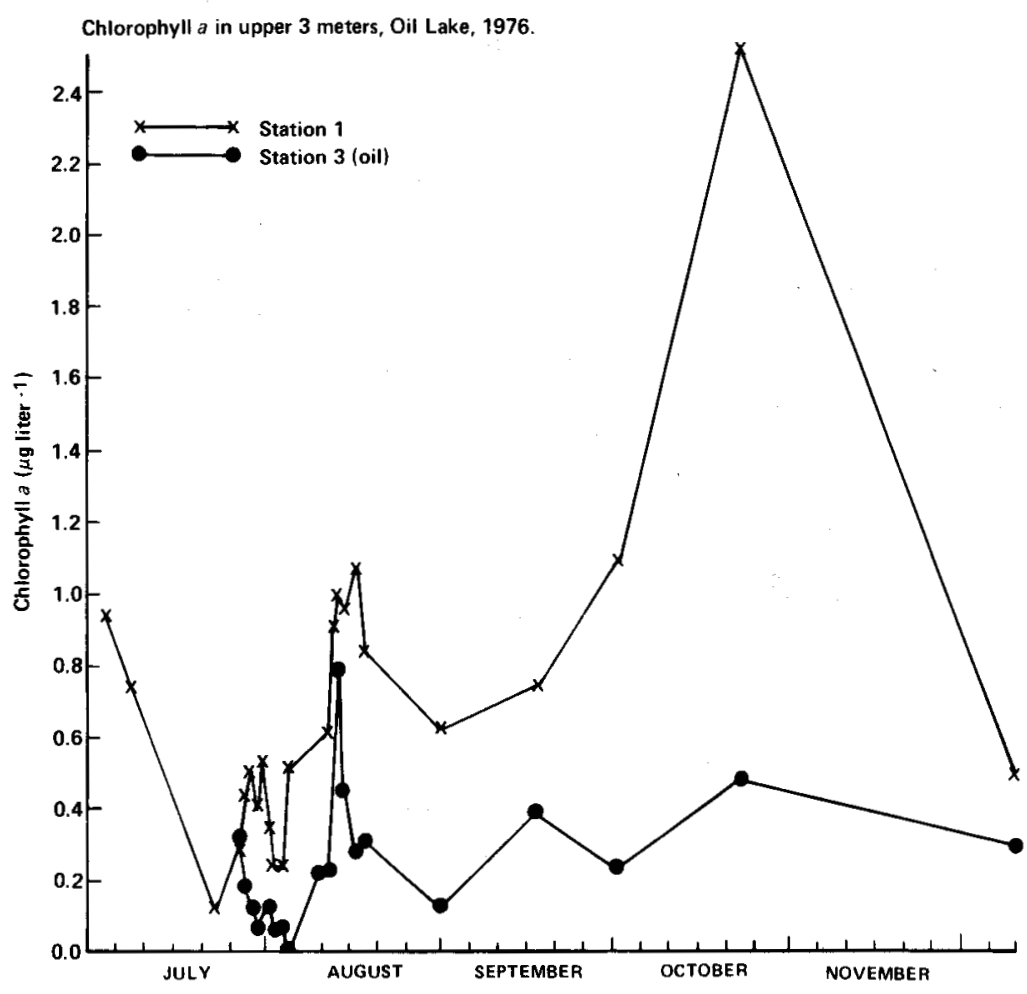

FIG. 11. Average chlorophyll $a$ concentration in the upper three metres on the inside and outside of the sea curtain in Oil Lake during 1976. 


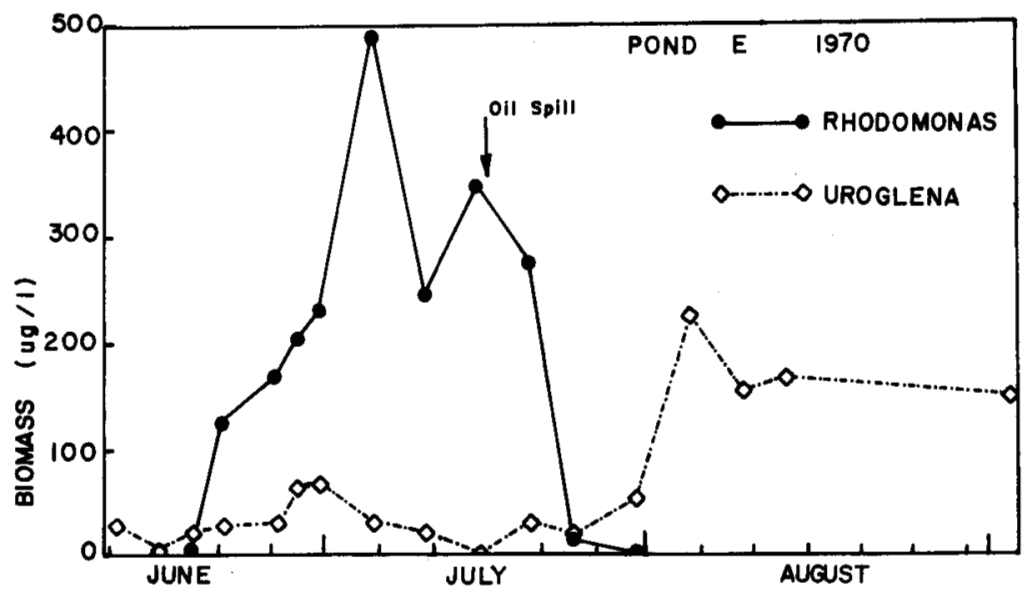

A

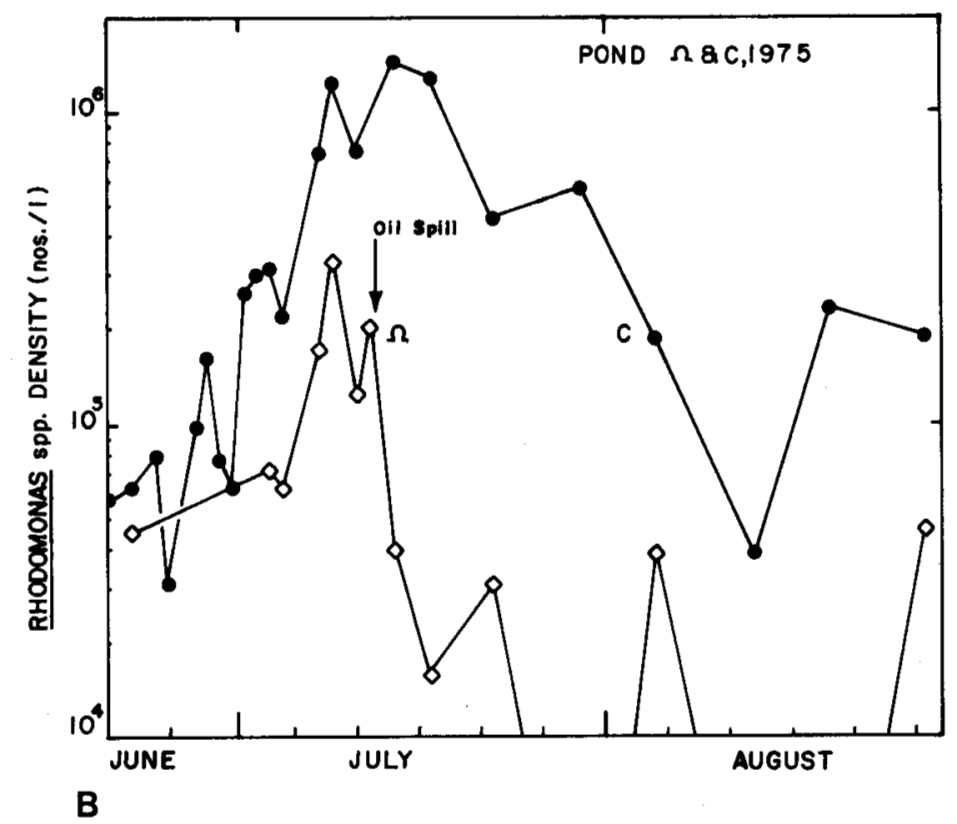

FIG. 12. a. Biomass of Rhodomonas and Uroglena Omega and E, 1970. b. The density of Rhodomonas sp. (Cryptophyta) in control Pond C and oil spill Pond Omega in 1975. 
TABLE 3. Nutrient concentrations before and after whole pond spills on Pond E and Pond Omega compared to Pond C, the control pond (yearly average \pm std. dev.)

\begin{tabular}{|c|c|c|c|c|c|c|c|c|}
\hline Parameter-Pond/Year & & $\begin{array}{r}1970 \\
\text { Prespill }\end{array}$ & $\begin{array}{c}1970 \\
\text { Postspill }\end{array}$ & 1971 & 1972 & $\begin{array}{r}1975 \\
\text { Prespill }\end{array}$ & & $\begin{array}{r}1975 \\
\text { Postspill }\end{array}$ \\
\hline \multirow{3}{*}{$\begin{array}{l}\text { Dissolved } \\
\text { Reactive } \\
\text { Phosphate } \\
\left(\mu \mathrm{g}^{2} . \mathrm{PO}_{4}-\right. \\
\left.\mathrm{P}^{-1}\right)\end{array}$} & Pond C & $\begin{array}{l}0.066^{1} \\
(.042)\end{array}$ & $\begin{array}{l}0.082^{1} \\
(.029)\end{array}$ & $\begin{array}{l}.071^{1} \\
(.04)\end{array}$ & $\begin{array}{l}0.064^{1} \\
(.01)\end{array}$ & $\begin{array}{l}0.24^{2} \\
(.13)\end{array}$ & & $\begin{array}{l}0.38^{2} \\
(.58)\end{array}$ \\
\hline & Pond E & $\begin{array}{l}0.052 \\
(0.03)\end{array}$ & $\begin{array}{l}0.076 \\
(.048)\end{array}$ & $\begin{array}{l}0.059 \\
(.05)\end{array}$ & $\begin{array}{l}0.082 \\
(.04)\end{array}$ & & $\begin{array}{l}0.28 \\
(.21)\end{array}$ & \\
\hline & Pond Omega & & & & & $\begin{array}{l}0.43 \\
(.30)\end{array}$ & & $\begin{array}{l}0.43 \\
(.62)\end{array}$ \\
\hline \multirow{3}{*}{$\begin{array}{l}\text { Ammonium } \\
\left(\mu \mathrm{g} \text { at. } \mathrm{NH}_{3}-\right. \\
\left.\mathrm{N}^{-1}\right)\end{array}$} & Pond C & $\begin{array}{l}2.9 \\
(1.6)\end{array}$ & $\begin{array}{l}1.4 \\
(0.4)\end{array}$ & $\begin{array}{l}2.6 \\
(0.8)\end{array}$ & & $\begin{array}{l}2.4 \\
(2.3)\end{array}$ & & $\begin{array}{l}2.7 \\
(2.0)\end{array}$ \\
\hline & Pond E & $\begin{array}{l}2.8 \\
(1.2)\end{array}$ & $\begin{array}{l}1.2 \\
(0.3)\end{array}$ & $\begin{array}{l}2.1 \\
(1.9)\end{array}$ & & & $\begin{array}{l}1.6 \\
(0.8)\end{array}$ & \\
\hline & Pond Omega & & & & & $\begin{array}{l}2.8 \\
(1.2)\end{array}$ & & $\begin{array}{l}2.2 \\
(1.5)\end{array}$ \\
\hline \multirow{3}{*}{$\begin{array}{l}\text { Nitrate } \\
\left(\mu \mathrm{g}_{\text {at. }} \mathrm{NO}_{3}-\right. \\
\left.\mathrm{N} \mathrm{1}^{-1}\right)\end{array}$} & Pond C & $\begin{array}{l}0.64 \\
(.47)\end{array}$ & $\begin{array}{l}0.03 \\
(.05)\end{array}$ & $\begin{array}{l}1.30 \\
(1.1)\end{array}$ & & $\begin{array}{l}1.0 \\
(1.1)\end{array}$ & & $\begin{array}{l}0.88 \\
(.74)\end{array}$ \\
\hline & & $\begin{array}{l}0.57 \\
(.58)\end{array}$ & $\begin{array}{l}0.27 \\
(0.8)\end{array}$ & $\begin{array}{l}2.9 \\
(2.6)\end{array}$ & & & $\begin{array}{l}2.8 \\
(3.8)\end{array}$ & \\
\hline & Pond Omega & & & & & $\begin{array}{l}2.6 \\
(1.5)\end{array}$ & & $\begin{array}{l}1.0 \\
(0.7)\end{array}$ \\
\hline \multirow{3}{*}{ 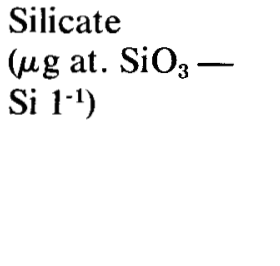 } & Pond C & $\begin{array}{l}4.2 \\
(5.7)\end{array}$ & $\begin{array}{l}9.4 \\
(7.6)\end{array}$ & $\begin{array}{l}2.3 \\
(0.9)\end{array}$ & & $\begin{array}{l}3.4 \\
(2.6)\end{array}$ & & $\begin{array}{l}1.5 \\
(1.5)\end{array}$ \\
\hline & Pond E & $\begin{array}{l}3.5 \\
(2.4)\end{array}$ & $\begin{array}{l}8.6 \\
(4.3)\end{array}$ & $\begin{array}{l}2.9 \\
(1.8)\end{array}$ & & & $\begin{array}{l}8.9 \\
(10.3)\end{array}$ & \\
\hline & Pond Omega & & & & & $\begin{array}{l}1.8 \\
(1.0)\end{array}$ & & $\begin{array}{l}1.6 \\
(0.7)\end{array}$ \\
\hline
\end{tabular}



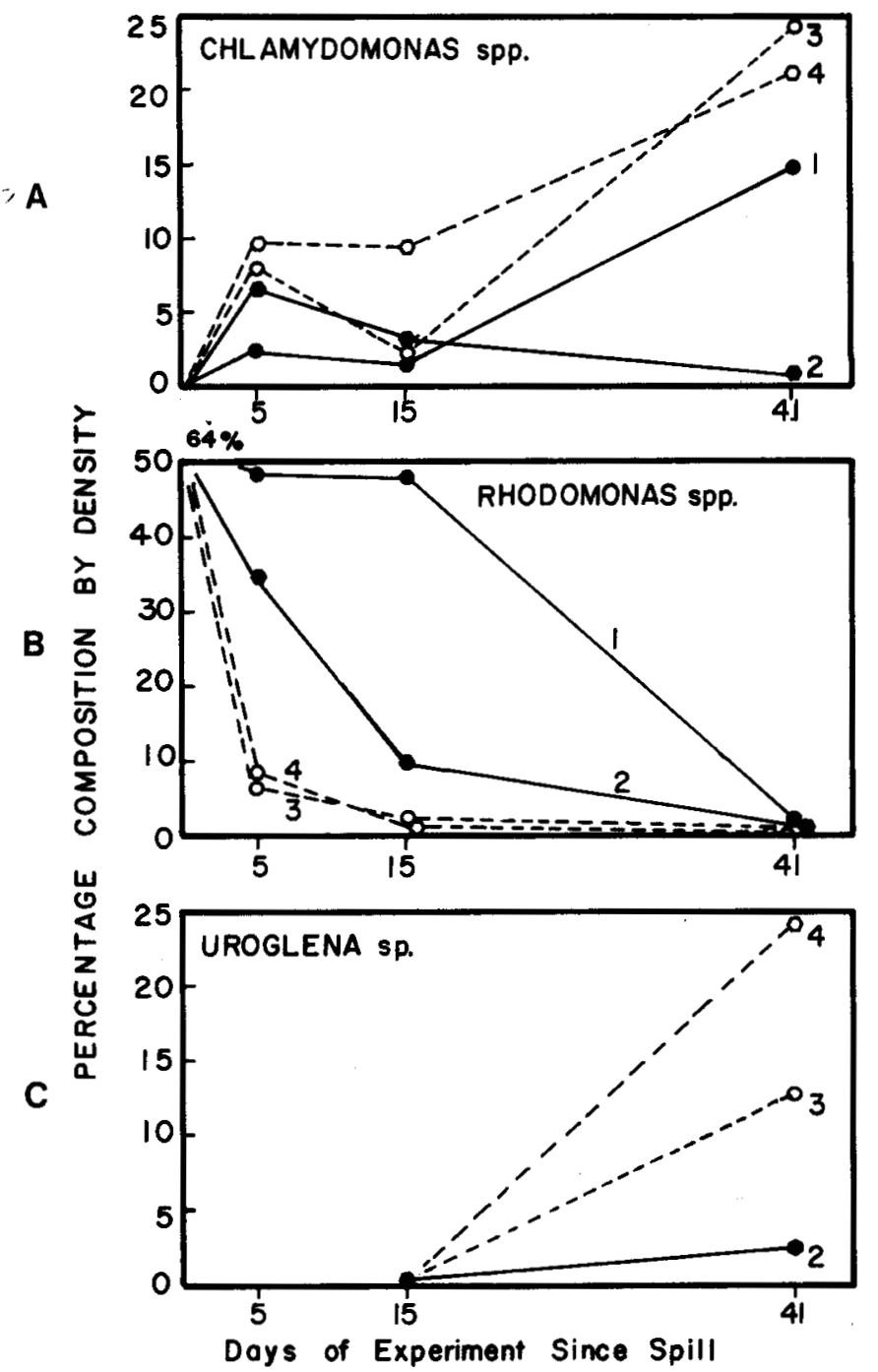

FIG. 13. Changes in percentage compostion by number of selected species of phytoplankton that became more abundant or were eliminated in subponds during 1976 (Treatment $1=$ no oil + zooplankton; Treatment $2=$ no oil - zooplankton; Treatment $3=$ plus oil + zooplankton; Treatment 4 = plus oil - zooplankton).

dominant. Similarly, the Cryptophytes declined in the zooplankton-free subpond (treatment 2) (Fig. 13). In contrast, in the zooplankton (treatment 1) control pond, Rhodomonas continued to comprise $40 \%$ of the algal biomass after 15 days.

After 41 days, no species present at time zero had been eliminated from the plankton in treatment 1 . Rhodomonas was rare ( $2 \%$ of volume) as it was also by that time in Pond C (Federle et al., 1978), Chrysophytes (Chromulina, 
Chrysococcus and Ochromonas) still dominated. The zooplankton-free control subpond (treatment 2 ) became dominated ( $83 \%$ by volume) by a Dinobryon sp. not detected in any other treatment. The oil-treated subponds (treatments 3 and 4) both showed co-dominance by Chlamydomonas (Chlorophyta), Uroglena sp. (Chrysophyta) and Oscillatoria (Cyanophyta) (Federle et al., 1978). Uroglena, which had been an indicator of oil in the whole-pond spills was not seen in the zooplankton treatment or in control Pond C (Miller et al., 1978). It represented 23 to $14 \%$ of the biomass in the oil-treated subponds and was present in the zooplankton-free subpond. Also, a blue-green alga Oscillatoria sp. (Cyanophyta) which was not seen in any of the untreated subponds or in Pond C, appeared in the two oil treatments ( 3 and 4 ) as the dominant genus. Changes induced by oil treatment at the dose level used in Pond Omega appeared similar in many ways to those occurring in that whole pond spill. However, the changes in the zooplankton-free treatment were similar to the species changes found in Pond Omega one year after the spill (5 July 1976): Uroglena, Chlamydomonas, Dinobryon and Ochromonas were present in a Chrysophyte dominated flora.

\section{Physical-Chemical-Nutrient Changes}

The oil may have altered physical-chemical conditions below the floating oil which caused in turn changes in species composition. Measurements of temperature, light, oxygen, $\mathrm{PO}_{4}{ }^{-3}, \mathrm{NO}_{3}{ }^{-1}, \mathrm{NH}_{4}{ }^{+1}, \mathrm{SiO}_{3}{ }^{-2}, \mathrm{pH}$, alkalinity and major cations show no apparent significant difference from Control Pond $\mathrm{C}$, except under the heavy black floating oil shortly after the spills at one margin of the pond (Table 3). Following the 1970 spill on Pond E, water temperature was about $4{ }^{\circ} \mathrm{C}$ higher for three days after the spill while oil was floating over the water, decreasing the albedo of the surface and reducing evaporative cooling (Barsdate, pers. comm.). However, seasonal water level decline and similar increases in depth of thaw between control Pond $\mathrm{C}$ and Pond $\mathrm{E}$ were not significantly different, indicating no dramatic change in heat budget. Dissolved oxygen saturation can be reduced by sediment respiration in the shallow water column. Under floating oil seven days after the Pond E spill, dissolved oxygen was reduced to a level $6 \%$ of the open water values on the west side of the pond (23 July 1970). In Pond Omega under floating oil, oxygen saturation was always greater than $50 \%$ of the open water values on the dates tested (10 July, 11 July and 15 August 1975). Anaerobic conditions were not observed or indicated (by odor of $\mathrm{H}_{2} \mathrm{~S}$ ).

Dissolved nutrients (dissolved reactive phosphorus, nitrate, ammonium and silicate) were measured throughout the ice-free period before and after the pond and lake oil spills (Table 2). Extracted dissolved reactive phosphorus (in isobutanol) ranged from $0.05-0.08 \mu \mathrm{g}$ at. $1^{-1}$ in open water season with no significant difference between control Pond C, Pond E and Pond Omega.

Although analysis of nutrients in Oil Lake is incomplete and in preparation (Alexander and Barsdate) preliminary data suggested that nutrient concentrations were slightly higher inside the boom during the summer of 1976. Much dissolved phosphorus is brought into the spilimnion of the lake in 
an organic form by the snow melt and rainfall runoff from the terrestrial watershed in spring and autumn and by autumn thermal overturn. Even on the date of the highest measured phosphorus concentration (23 October 1976, Fig. 14), dissolved reactive phosphorus and particulate phosphorus were within a few ug P $1-^{1}$ of each other (Barsdate and Alexander, in preparation). Nitrogen fixation by the Oil Lake microbiota on two dates in July and August, 1976 at 0.5 and $2.0 \mathrm{~m}$ was too low to be important in terms of nitrogen input and was not significantly different inside and outside the boom (Table 4). Thus, most nutrient parameters were not different or only slightly higher inside the boom than outside.
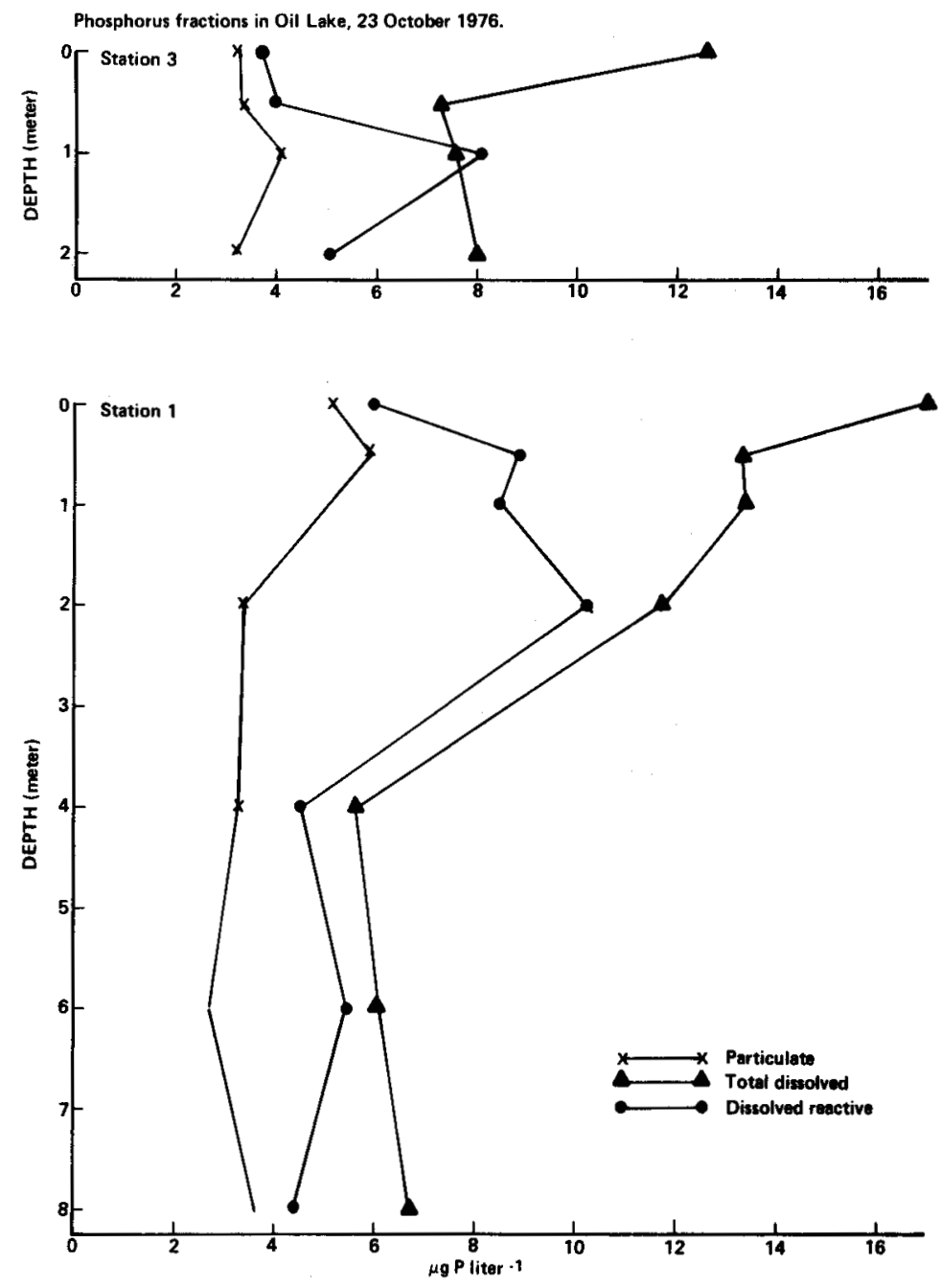

FIG. 14. Dissolved and particulate phosphorus species (ug $\mathbf{P}^{1-1}$ ) in depth profiles inside and outside the sea curtain in Oil Lake, 23 Oct. 1976. 


\section{DISCUSSION}

Of the several possible effects oil may have on the phytoplankton, many may be evaluated from the Barrow ponds and Oil Lake experiments. First, phytotoxicity reduced primary production for the first four days in whole pond spills where measured and in subponds. Ochromonas and Mallomonas (Chrysophyta) were eliminated from subponds within five days and the loss rate of Rhodomonas (Crypotphyta) was faster than in the zooplankton-free subpond (Miller et al., 1977; Fig. 12). This phytotoxicity is suggested at least for some species. Soto et al., (1975) showed that the percentage cell death in Chlamydomonas was a function of the length of time the soluble aromatic hydrocarbons were contained in the water. Opened to the atmosphere, growth began within 24 hours, at least in cultures. This is consistent with the observed depression of photosynthesis immediately following oil spill and some short term elimination of some species of algae. However, in these shallow ponds, the initial toxicity did not last more than five days. In the contained lake spill, the toxicity appeared to inhibit algal production and biomass accumulation inside the oil curtain during all of the first year.

Secondly, toxicity by prolonged exposure to weathered oil is simply not known because the data are ambiguous. In the Cape Simpson seeps, the primary production and algal biomass were actually enhanced by increased contact with old oil tars, but zooplankton were also reduced over the same gradient (Barsdate et al., 1973). In Pond Omega and in Oil Lake, the algal biomass and algal productivity was reduced throughout most of the second summer. These two observations are consistent with such phytotoxicity by persistent components of crude oil. Even with the elimination of zooplankton, elevated water levels in the spring and ice disturbance of the littoral tar deposits could have exposed the water to fresh oil in the spring. In the contained lake spill there was suppression of the spring bloom under the ice inside the boom in the second year. In Pond Omega there was reduced primary production and algal biomass during the first two months of the summer, ice-free season in the second year.

Thirdly, hypotheses about modification of primary productivity by floating oil changing physical-chemical growth conditions does not seem to be plausible since floating oil covers such small portions of the pond or lake and for such short periods of time. Forthly, nutrient concentrations in the spill

TABLE 4. Nitrogen-fixation in Oil Lake in 1976 following the contained spill (ngm $\mathrm{N}$ liter $-^{-1}$ hr $-^{-1}$ ) (July 29 and Aug. 9, 1976)

\begin{tabular}{lccc}
\hline & Mean \pm & Std. Dev. & No. \\
\hline Station 1 - outside boom & 23.6 & 2.8 & 12 \\
Station 3 - inside boom & 29.7 & 3.0 & 18 \\
\hline
\end{tabular}


ponds and contained spill on Oil Lake were not significantly different than control areas. Sestonic nitrogen was found to increase in Lakes $4 \mathrm{C}$ and 8, Northwest Territories, in one case more than the nitrogen contained in the oil assuming complete mineralizaton within the first year (Snow and Rosenberg, 1975b; Roeder et al., 1975; Snow and Scott, 1975). Schindler et al., (1975) reported an increase in nitrate inside polyethylene-lined ponds in the Ottawa River. There was little increase in N-fixing blue-green algae, but a reported 10 -fold increase in numbers of nitrogen-fixing bacteria in his work. We made direct measurements of nitrogen fixation using the acetylene reduction method. Higher values occurred on one of three dates on Pond E in 1972 in the third summer after the spill. Although the question remains unresolved as to whether nitrogen fixation was induced in these arctic ponds by oil, it did not increase the concentration of dissolved nitrogen (Table 2). Furthermore, the measured nitrogen fixation rates were not significant compared with ammonification in sediments (Barsdate and Prentki, 1973).

We did not find any increase in pool sizes of nitrogen in Pond $\mathrm{E}$ in 1971, one year after the spill including $\mathrm{NO}_{3^{-}}+\mathrm{NO}_{2^{-}}, \mathrm{NH}_{4}+$, DON, Particulate $\mathrm{N}$ (Barsdate and Prentki, 1973) and no increases in DIN in the year of the spill, 1970 (Table 3). Rates of ammonification and nitrogen fixation similarly showed no differences (Barsdate and Prentki, 1973; Alexander and Schell, 1973). In these oligotrophic ponds, complete mineralization of all nutrients from the oil would have meant a total release of $19.5 \mathrm{ugN} / \mathrm{l}$ on Pond E and 2.4 ugN/1 on Pond Omega (Table 1). The biodegradation of Prudhoe crude oil must not be very rapid since the total $\mathrm{N}$ in the water (PN, DON, DIN) was less than $1 \mathrm{mg} / 1$ in Pond E (1971). In Prudhoe crude oil, the residuum from high temp distillation amounts to $36.3 \%$ of the total volume and it is twice as rich in $\mathbf{S}$ and $\mathbf{N}$ as the whole oil. Significantly, the bulk of the nutrient elements are bound in the most refractory, non-volatile part of the oil, the tars. Even with a very large source of $\mathrm{N}$ in the oil, most of it apparently remained in sediment in the littoral area, where it was estimated $50 \%$ of the oil remained one year after the Pond $\mathrm{E}$ spill. No detectable increase in algal biomass, dissolved organic or inorganic $\mathrm{N}$, suggested that little, if any, was available.

Many of the effects seen with oil application in our studies on ponds seem to be adequately explained by the elimination of zooplankton at fairly low doses of oil (O'Brien, this volume). In all spills, all of the dominant zooplankton grazers were eliminated with five days. Despite the apparent decrease in rates of algal productivity following the whole pond application for two years, the algal biomass increased in the month or two after the spills to levels higher than prespill or control ponds. In the ponds, where the grazing rate may have been able to filter the water daily in mid-summer, the elimination of zooplankton resulted in the accumulation of algae despite the reduced productivity. Only in the oligotrophic Oil Lake did algal biomass and productivity both decline. Because zooplankton densities and average size of animals were so much lower and smaller, this decline is probably less related to reduced grazing than to other effects of the oil. 
Following the application of oil to the subponds, in which the interaction of algal biomass and zooplankton was the clearest, the algal biomass increased after an immediate oil toxicity to reach a concentration equivalent to that in the zooplankton-free subponds. The elimination of zooplankton experimentally, or by adding oil, allowed the phytoplankton to increase in biomass freed from grazing pressure. Because no external nutrients were available after the experiment was set up, maximum algal biomass may be a measure of nutrient availability with no grazing (treatments $2,3,4)$. The algal biomass attained in the oil-treated ponds was the same as that in the zooplankton-free subpond after 41 days. Following oil application, we conclude that increases in algal biomass in grazing-dominated systems are more a function of reduced grazing pressure on phytoplankton than upon release of nutrients from oil mineralization.

Both the addition of oil and the experimental elimination of zooplankton in subponds caused the demise of several algal species, particularly Rhodomonas sp. In the zooplankton-free subpond, Dinobryon sp. became dominant ( $83 \%$ by density). This species was not seen in any other subpond treatment but was common ( $15 \%$ by density) in the plankton of the control Pond C. And this occurred when grazing pressure was being reduced by diapause and death of zooplankton by Heterocope sp. late in the season (Dodson, 1975; Stross, 1974). In the oil-treated subponds, a filamentous non-heterocystous blue-green alga Oscillatoria became very common ( $27 \%$ by density). Development of the blue-green algae following an oil spill is similar to findings with Norman Wells crude oil in Lake 4, Lake C and Lake 8, North West Territories (Snow and Rosenberg, 1975a, 1975b; Snow and Scott, 1975; Roeder et al., 1975). However, the increase in blue-greens was not apparently caused by increases in available nutrients, but some other effect of the oil not fully understood. Many of the changes in phyto-species composition that occur after oil spills may be caused by the reduction of grazing pressure by the acute toxicity of the oil to Cladocera and fairy shrimp.

In our experimental contained lake spill, the decrease in primary productivity and chlorophyll in the oil spill are not consistent with the grazing hypothesis. However, in the lake system the grazing pressure is qualitatively much lower than in the Barrow ponds, so that the effects of removal of the zooplankton was not nearly so dramatic (Haney, personal communication).

In conclusion, the strongest evidence from the Barrow ponds indicates that the repeated change in phyto-species composition following crude oil spills over a hundred-fold range in dose is caused by the elimination of the grazers. Recovery of the phytoplankton to prespill composition has not occurred after six years. It will probably not happen until the zooplankton are capable of developing to their prespill density. Daphnia middendorfiana because of its size and density is probably the key species. This species, although it may colonize Pond E during the period of overland flow until late June, did not complete its life cycle in Pond E as of 1975 (Stross 1974; O'Brien 1978). After seven years, the zooplankton Daphnia had not been observed to survive through the entire summer. In the phytoplankton Rhodomonas sp. similarly has 
only recently been observed in the plankton of Pond $E$ in low densities. This food chain dependent maintenance of the algal composition considered 'normal' for these ponds is evidence of the interrelatedness between trophic levels. The long-term effects of the oil on pond phytoplankton seem related to slow recovery of the zooplankton. This could be confirmed by establishing a subpond of Pond Omega water and adding to it the average zooplankton density which, if the hypothesis holds, should develop a Chrysophyte-Cryptophyte dominated flora.

Oil Lake showed repression of algal photosynthesis for two years after the spill, despite the fact that nutrient concentrations were slightly higher than the central station and zooplankton were reduced.

Our data have compared effects of oil on primary producers in zooplankton-dominated shallow tundra ponds and in a deeper, high energy littoral zone, where grazing was not nearly as important. Effects of oil are predictable, reproduceable and surprisingly long-lived in a community of organisms which reproduce rapidly and hence have the capability to recover quickly when conditions permit. Phytoplankton respond to oil, to altered nutrient availability and grazing, and make excellent indicators to examine for oil pollution effects.

\section{ACKNOWLEDGEMENTS}

Principal support for this research was through grants from the Energy Research and Development Administration to V. Alexander, University of Alaska and to J. E. Hobbie, Marine Biological Laboratory, Woods Hole, Mass. (Grant No. E(45-1)2229-T 10); through grants from the National Science Foundation (Division of Biology and Medicine and Office of Polar Programs) to V. Alexander to R. J. Barsdate, University of Alaska, and to M. C. Miller, University of Cincinnati, as part of the integrated research for the aquatic program of the Tundra Biome for the International Biological Program (Grants No. GV-29342); through grants from the National Science Foundation; Division of Polar Programs to V. Alexander, to M. C. Miller and to R. J. Barsdate as part of the coordinated program "R.A.T.E." (Research on Arctic Tundra Environments) (Grants No. NSF OPP75-12945 and NSF OPP75-12948) and a grant to R. J. Barsdate from the Environmental Protection Agency (R 804152020).

Field and laboratory activities at Barrow were supported under contract by the Naval Arctic Research Laboratory, and field activities on the North Slope of the Brooks Range were supported by the Biome Center, College of Environmental Sciences, University of Alaska, Fairbanks.

Special thanks are due to the field work and phytoplankton enumeration of Gary $\mathbf{R}$. Hater. Assistance with field work was provided by J. Cornwell, D. Pederson, K. Muellor and others.

\section{REFERENCES}

ALEXANDER, V., R. ClASBY and C. COULON. 1972. Primary productivity studies in the Barrow tundra ponds. Manuscript report. University of Alaska. $23 \mathrm{p}$.

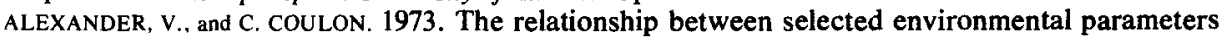
and aquatic primary productivity. United States Tundra Biome Data Report 73-5. U.S. I.B.P. 53p.

ALEXANDER, V. and D. M. SCHELL. 1973. Nitrogen fixation in arctic and alpine tundra. U.S. Tundra Biome Data Report 73-20. U.S. I.B.P. 55p. 
BARSDATE, R. J., V. ALEXANDER, and R. E. BENoIt. 1973. Natural oil seeps at Cape Simpson, Alaska. Aquatic Effects. In Proceedings of the Symposium on the Impacts of Oil Resource Development on Northern Plant Communities. pp. 91-95. Occasional Publication on Northern Life No. 1. University of Alaska, Fairbanks.

BARSDATE, R. J. and R. J. PRENTKI. 1973. Nutrient metabolism and water chemistry in lakes and ponds of the arctic coastal tundra. Tundra Biome Data Report 73-27. U.S. I.B.P.

DODSON, S. 1975. Predation rates of zooplankton in arctic ponds. Limnology and Oceanography. 20: 426-433.

FEDERLE, T. W., J. R. VESTAL, G. R. HATER and M. C. MILLER. 1978. The effect of Prudhoe Bay crude oil on primary production and zooplankton in arctic tundra thaw ponds. Marine Environmental Research 1.

HOBBIE, J. E., R. J. BARSDATE, V. ALEXANDER, D. W. STANLEY, C. P. McROY, R. G. STROSS, D. A. BIERLE, R. D. DILLON, M. C. MILLER, P. I. COYNE, and J. H. KELLEY. 1972. Carbon flux through a tundra pond ecosystem at Barrow, Alaska. U.S. Tundra Biome Report. 74-4. U.S. I.B.P. 44p.

MILLER, M. C. and J. P. REED. 1973. Benthic metabolism, primary production of phytoplankton, bacterial heterotrophy, and organic carbon in Barrow tundra ponds, 1971-1972. U.S. Tundra Biome Data Report 73-14. U.S. I.B.P. 74p.

MILLER, M. C., J. R. VESTAL, S. MOZLEY, M. BUTLER and J. E. HOBBIE. 1977. Effects of Prudhoe crude oil spills on coastal tundra ponds. P. 521-529. In Energy/Environment II U.S. EPA-600/9 -77-012.

MILLER, M. C., G. R. HATER and J. R. VESTAL. 1978. Effects of Prudhoe crude oil on carbon assimilation by planktonic algae in an arctic pond. In Adriano, D. C. and I. L. Brisbin (eds.) Environmental Chemistry and Cycling Processes. E.R.D.A. Symposium Series, CONF 760429. National Tech. Center, Oak Ridge, Tenn.

O'BRIEN, W. JOHN. 1978. Toxicity of Prudhoe Crude Oil to Alaskan Arctic zooplankton. Arctic (this volume).

ROEDER, D. R., G. H. CRUM, D. M. ROSENBERG and N. B. SNOW. 1975. Effects of Norman Wells crude oil on periphyton in selected lakes and rivers in the Northwest Territories. Fisheries Marine Service. Technical Report 552. Environment Canada.

SCHINDLER, D. W. 1969. Two useful devices for vertical plankton and water sampling. Journal of the Fisheries Research Board Canada. 28: 1948-1955.

SCHINDLER, D. B., B. F. SCOTT and D. B. CARLISLE. 1975. Effect of crude oil on populations of bacteria and algae in artificial ponds subject to winter and ice formation. Verhandlungen Internationale Vereinigung Fur Theoretische und Angewandte Limnologie. 19:2138-2144.

SNOW, N. B. and D. M. ROSENBERG. 1975. Experimental oil spills on MacKenzie Delta Lakes I. Effect of Normal Wells crude oil on Lake 4. Fisheries Marine Service Technical Report No. 548. Environment Canada.

1975b. Experimental oil spills on MacKenzie Delta Lakes 11. Effect of two types of crude oils Lakes 4C and 8. Fisheries Marine Service Technical Report No. 549. Environment Canada.

SNOW, N. B. AND B. F. SCOTT. 1975. The effect and fate of crude oils spilt on two arctic lakes. In Conf. on Prevention and Control of Oil Pollution, American Petroleum Institute, Washington, D.C.

SOTO, C., J. A. HELLEBUST and T. C. HUTCHINSON. 1975. The effects of aqueous extracts of crude oil and naphthalene on the physiology and morphology of a freshwater green algae. Verhandlungen Internationale Vereinigung Fur Theoretische und Angewandte Limnologie. 19: 2145-2154.

STANLEY, D. W. 1973. Benthic algae productivity in tundra ponds. U.S. Tundra Biome Report 73-18. U.S. I.B.P. 70p.

, 1976. Productivity of epipelic algae in tundra ponds and lake near Barrow, Alaska. Ecology. 57: 1015-1024.

STRICKLAND, J. D. H. and T. R. PARSONS. 1968. A manual of sea water analysis. Bulletin of the Fisheries Research Board, Canada. 165: $311 \mathrm{p}$.

STROSS, R. G. 1974. Zooplankton synchrony and productivity in arctic coastal ponds at Barrow, Alaska. U.S. Tundra Biome Report. 74-4. U.S. I.B.P. 64p.

THOMPSON, C. J., H. J. COLEMAN, J. R. DOOLEY and D. E. HIRSCH. 1971. Bumines analysis shows characteristics of Prudhoe Bay crude. Oil and Gas Journal. 69: 112-120.

UTERMOHL, H. 1958. Zur Vervollkommung der quantitative Phytoplankton Methodik. Mitteilungen Internationale Vereinigung Fuer Theoretische und Angewandte Limnologie. 9: 1-38.

VOLLENWEIDER, R. A. 1969. A manual on methods for measuring primary production in aquatic environments. F. A. Davis Co., Philadelphia. 